Toxicology Volume 229, Issues 1-2, 5 January 2007, Pages 11-22

doi:10.1016/j.tox.2006.09.003

Copyright (c) 2006 Elsevier Ireland Ltd All rights reserved.

\title{
In vitro tests to evaluate immunotoxicity: A preliminary study
}

\author{
M. Carfi'a, d, * A. Gennaria , I. Malerba ${ }^{a}$, E. Corsinib ${ }^{b}$ M. Pallardy ${ }^{c}$, R. \\ Pieters $^{d}$, H. Van Loveren ${ }^{\mathrm{e}}$, H.W. Vohr ${ }^{\mathrm{f}}$, T. Hartung ${ }^{a}$ and L. Gribaldo \\ ${ }^{a}$ ECVAM, IHCP, JRC, 21020 Ispra (VA), Italy \\ baboratory of Toxicology, Department of Pharmacological Sciences, 20133 Milan, \\ Italy \\ 'Laboratoire Toxicologie, INSERM U461 Faculté de Pharmacie Paris XI, 92290 \\ Chatenay-Malabry, France \\ ${ }^{d}$ IRAS-Immunotoxicology, Utrecht University, 3508 TD Utrecht, The Netherlands \\ eNational Institute of Public Health and the Environment, 3720 BA Bilthoven, The \\ Netherlands \\ fBayer Health Care, Institute of Molecular and Genetic Toxicology, 42096 \\ Wuppertal, Germany
}

Received 19 July 2006; revised 5 September 2006; accepted 6 September 2006. Available online 10 September 2006.

* Corresponding author at: ECVAM, IHCP, JRC, 21020 Ispra (VA), Italy. Tel.: +39 0332789067 ; fax: +390332785336.

\section{Abstract}

The implementation of Registration, Evaluation and Authorisation of new and existing Chemicals (REACH) will increase the number of laboratory animals used, if alternative methods will not be available. In the meantime, REACH promotes the use of in vitro tests and, therefore, a set of appropriated alternative testing methods and assessment strategies are needed.

The immune system can be a target for many chemicals including environmental contaminants and drugs with potential adverse effects on human health. The aim of this study was to evaluate the predictivity of a set of in vitro assays to detect immunosuppression. The tests have been performed on human, rat and murine cells. Different endpoints have been assessed: cytotoxicity, cytokine release, myelotoxicity and mitogen responsiveness. For each of these endpoints IC50s values have been calculated.

Six chemical substances, representative of the full range of in vivo responses and for which good human and/or animal data are available either from databases or literature, have been selected: two chemicals classified as not immunotoxic (Urethane and Furosemide), and four (tributyltin chloride (TBTC), Verapamil, Cyclosporin A, Benzo(a)pyrene) with different effect on immune system.

All the tests confirmed the strong immunotoxic effect of TBTC as well as they confirmed the negative controls. For one chemical (Verapamil) the IC50 is similar through the different tests. The IC50s obtained with the other chemicals depend on the endpoints and on the animal species. 
Toxicology Volume 229, Issues 1-2, 5 January 2007, Pages 11-22

The clonogenic test (CFU-GM) and the mitogen responsiveness showed similar IC50s between human and rodent cells except for Cyclosporin A and TBTC.

All different tests classified the compounds analyzed in the same way.

\section{Introduction}

In October 2003 the European Commission adopted a new EU regulatory framework for chemicals (COM, 2003 644). Under the proposed new system called Registration, Evaluation and Authorization of Chemicals (REACH) enterprises that manufacture or import more than 1 tonne of a chemical substance per year would be required to register it in a central database. REACH would give greater responsibility to industry to manage the risks from chemicals and to provide safety information on the substances. The aim is to improve the protection of human health and environment through the better and earlier identification of the properties of chemical substances.

In vivo studies are very expensive, require a high number of animals and raise important ethical concern. For this reason the European policy is promoting alternative methods to the use of laboratory animals, in order to reduce and whenever possible replace animals employed for scientific studies and costs (Balls et al., 1995). Different institutes are developing in vitro tests able to predict compound's effects in vivo. In vitro methods standardized and validated have replaced or reduced some in vivo tests (Genshow et al., 2002 and Pessina et al., 2003).

Among important target organs of chemical exposure is the immune system. Immunotoxicity can be defined as the adverse effect of chemicals or agents on the immune system. The effect may be increased immune activity, manifested as either hypersensitivity or autoimmunity, or decreased immune activity, with reduced ability to fight infectious agents and increased incidence of cancer (Snodin, 2004).

A workshop, held at ECVAM in 2003 (Gennari et al., 2005), reports the state of the art of in vitro systems for evaluating immunotoxicity. This project is based on workshop recommendations and is focused on immunosuppression.

The purpose of this study was to compare the predictivity of several in vitro tests, i.e. proliferation assays and cytokine production using both human and rodent cells. A panel of six substances was selected: four positive and two negative compounds, chosen among drugs and chemicals. The four with known toxic effects on immune system were: Verapamil, Benzo(a)pyrene, Cyclosporin A, Tributyltin chloride (TBTC). The two not immunotoxic were Urethane and Furosemide.

Verapamil is a calcium-channel blocker, used for hypertension and arrhythmias treatment. It has been shown that Verapamil inhibits, in a dose-dependent fashion, the proliferation of T-cells after mitogen stimulation (Birx et al., 1984 and Chow and Jusko, 2004).

Human exposure to Benzo(a)pyrene occurs primarily through cigarette smoking, inhalation of polluted air and by ingestion of food and water contaminated by combustion effluents. Benzo(a)pyrene is present as a major component of the total content of polynuclear aromatic compounds in the environment (IARC, 1983). In addition to being carcinogenic and mutagenic, Benzo(a)pyrene has 
been found to be potent immunosuppressant. Effects have been documented on cell-mediated immunity, humoral immunity, and on host resistance.

Cyclosporin $A$ is a powerful immunosuppressant with a specific action on Tlymphocytes. It is widely used to prevent organ graft rejection (Martindale, 2002b).

Tributyltin chloride (TBTC) is an organotin compound used as plastic stabilizer, catalytic agent, agricultural pesticide and as antifouling agent in paints. It causes thymus atrophy in rodents (Snoeij et al., 1987), depletion of lymphocytes in spleen and lymph nodes, lymphopenia and alteration of serum immunoglobulin levels (Kimura et al., 2005).

Urethane is utilized as a solubilizer and co-solvent in the manufacture of pesticides, fumigants, and cosmetics, as an intermediate for pharmaceuticals, and in biochemical research (HSDB, 2000). Furosemide is a potent diuretic. It is used in the treatment of oedema associated with heart failure, including pulmonary oedema, and with renal and hepatic disorders (Martindale, 2002a).

\section{Materials and methods}

\subsection{Drugs}

Urethane (99\%) was supplied by Sigma-Aldrich (St Louis, MO, USA); it was solved in water. Furosemide was supplied by APP (American Pharmaceuticals Partners, Schaumburg, IL), it was solved in water for injection. Verapamil hydrochloride was supplied by ABBOT LABORATORIES (North Chicago, USA) as water solution containing Verapamil hydrochloride $2.5 \mathrm{mg} / \mathrm{ml}$ and sodium chloride $8.5 \mathrm{mg} / \mathrm{ml}$. Benzo(a)pyrene ( $97 \%$ ) was supplied by Sigma-Aldrich and solved in DMSO. Cyclosporin A was supplied by BEDFORD LABORATORIES (Bedford, OH, USA) as Cyclosporin $50 \mathrm{mg}$, polyoxyethylated castor oil $650 \mathrm{mg}$, absolute alcohol $33.2 \%(\mathrm{v} / \mathrm{v})$ and water for injection. Tributyltin chloride (TBTC, 96\%) was supplied by Sigma-Aldrich and dissolved in DMSO.

Drug dilution of test compounds were prepared freshly for each experiment in DMSO (TBTC, Benzo(a)pyrene), water (Urethane) or in culture medium (Verapamil, Cyclosporin A, Furosemide).

The final concentration of DMSO never exceeded $0.5 \%$.

\subsection{CFU-GM assay}

Cord blood cells were seeded in MethoCult-H4001 medium (Methocult, StemCell Technologies, Vancouver, BC, Canada). This medium contains $1 \%$ of methylcellulose in IMDM, $30 \%$ FBS, $1 \%$ of Bovine Serum Albumin (BSA), 2 mM Lglutamine and $10 \mathrm{ng} / \mathrm{ml}$ granulocyte-macrophage-colony stimulating factor (GMCSF).

Briefly, $22 \mu \mathrm{l}$ of $200 \times$ drug solutions and $300 \mu \mathrm{l}$ of cells $\left(1.1 \times 10^{6}\right.$ cells $\left./ \mathrm{ml}\right)$ were added to tubes containing $4 \mathrm{ml}$ of MethoCult. About $1 \mathrm{ml}$ of methylcellulose-cell suspension was then seeded into the $35 \mathrm{~mm}$ Petri dishes.

The cultures were incubated at $37^{\circ} \mathrm{C}$ and $5 \% \mathrm{CO}_{2}$ under saturated humidity for 14 days. 
Toxicology Volume 229, Issues 1-2, 5 January 2007, Pages 11-22

The final concentrations of drugs were from $0.1 \mu \mathrm{M}$ to $160,000 \mu \mathrm{M}$ for Urethane, from $0.01 \mu \mathrm{M}$ to $150 \mu \mathrm{M}$ for Furosemide, from $0.1 \mu \mathrm{M}$ to $113 \mu \mathrm{M}$ for Verapamil, from $0.1 \mu \mathrm{M}$ to $200 \mu \mathrm{M}$ for Benzo(a)pyrene, from $0.1 \mu \mathrm{M}$ to $66.6 \mu \mathrm{M}$ for Cyclosporin A, from $0.001 \mu \mathrm{M}$ to $3.3 \mu \mathrm{M}$ for TBTC. 


\subsubsection{Source of progenitor cells}

Human cord blood cells were used as the source of progenitors for the CFUassays.

Cord blood cells were obtained, frozen, from Biopredic (Rennes, France) and thawed before using, as indicated by supplier. Cells were diluted in $30 \%$ FBSIMDM and used for the clonogenic test at a cell density of $1.1 \times 10^{6} \mathrm{cells} / \mathrm{ml}$.

\subsubsection{Colony scoring}

A CFU-GM (colony forming unit-granulocyte macrophage) colony is defined as an aggregate containing 50 or more cells. Morphologically, four classes of CFU-GM colonies can be observed: compact, diffuse and spread multicentric and multifocal colonies. A compact colony has a central dense nucleus with a peripheral halo. Diffuse and spread colonies are without an apparent nucleus. Multicentric colonies appear with two or more dense nuclei nearby and with a common peripheral halo growing at the same depth in the plate. Multifocal colonies are aggregates of several colonies or clusters with or without a peripheral halo (Pessina et al., 2001).

\subsubsection{Expression of results}

Cell proliferation is expressed as a percentage of growth, with respect to the number of colonies in control dishes (100\%).

Although the number of colonies scored in control plates, at a fixed density, varied between experiments performed on different days, differences in absolute colony counts did not affect the IC values. Colony formation linearity was used as acceptance criteria for colony growth in control dishes or well plates. In each experiment at least two different concentrations of cells were plated as described by Pessina et al. (2001).

The concentrations of test compound which inhibit growth by $50 \%$ of CFU-GM (IC50) in comparison with control cultures were calculated using the Hill function analysis.

Results are reported as the mean \pm standard error of at least two experiments, each done in triplicate.

\subsection{Cytokine release}

\subsubsection{Study protocol}

Peripheral blood was obtained from healthy subjects. Subjects were selected according to the guidelines of the Italian Health authorities and to the Declaration of Helsinki principles. Criteria for exclusion were abnormal laboratory values, medication known to affect the immune system, i.e. steroids and non-steroideal antinflammatory drugs, or patients suffering from malignancies, inflammations and infections. Subjects were enrolled among colleagues and were informed about methods and aims of the study. Blood samples $(5 \mathrm{ml})$ were taken by venous puncture with sodium citrate $0.5 \mathrm{M}$ as anticoagulant. Sodium citrate was chosen instead of heparin or EDTA as anticoagulant, since functional assays were performed using the whole blood assay and heparin may be contaminated with endotoxin, while EDTA interferes with cell activation. Blood was diluted 1:10 with 
cell culture medium RPMI 1640 (Sigma, St Louis, USA) containing 2 mM Lglutamine, $0.1 \mathrm{mg} / \mathrm{ml}$ streptomycin, $100 \mathrm{IU} / \mathrm{ml}$ penicillin as previously described (Kirchner et al., 1982).

\subsubsection{Cytokine production}

For the evaluation of cytokine production, cultures were set up in 24 well plate (Iwaki, Hasai, Japan) containing $0.5 \mathrm{ml}$ of $1: 10$ diluted whole blood in medium alone or in the presence of increasing concentrations of the selected chemicals and of lipopolysaccharide (LPS, from Escherichia coli serotype 0127:B8, Sigma) at final concentration of $1 \mu \mathrm{g} / \mathrm{ml}$ or phytohemagglutinin (PHA, Invitrogen, Paisley, UK) at final concentration of $1.2 \mu \mathrm{g} / \mathrm{ml}$. Cells were incubated for $24 \mathrm{~h}$ for LPSinduced TNF-a release and $72 \mathrm{~h}$ for PHA-induced IFN- $\gamma$ release at $37^{\circ} \mathrm{C}$ in a humidified $5 \% \mathrm{CO}_{2}$ incubator. Cell-free supernatants obtained by centrifugation at $1200 \mathrm{rpm}$ for $5 \mathrm{~min}$ were stored at $-20^{\circ} \mathrm{C}$ until measurement. Cytokine production was assessed by ELISA using commercially available kit (Immunotools, Friesoythe, Germany). Results are expressed in pg/ml. Each chemical was tested on three different donors.

\subsection{Proliferation with anti-CD3 stimulation}

\subsubsection{Human Iymphocytes proliferation}

Peripheral blood was collected by venous puncture on EDTA in human volunteers after filling an agreement form. Mononuclear cells (monocytes and lymphocytes) were isolated from peripheral blood (EDTA) using Ficoll hypaque gradient centrifugation (Pharmacia). Lymphocytes proliferation was induced using antiCD3 antibody (UCHT-1 clone) directed to the epsilon chain of the human CD3 complex. Anti-CD3 antibodies was precoated on 96 wells plates $24 \mathrm{~h}$ before adding the cells at room temperature $(4 \mu \mathrm{g} /$ well in $100 \mu \mathrm{l}$ of PBS). On the day of the experiment, complete media (RPMI 1640, penicillin, streptomycin, glutamine, sodium pyruvate, $10 \%$ fetal bovine serum) $50 \mu \mathrm{l}$, chemical $50 \mu \mathrm{l}$ and mononuclear cells $\left(4 \times 10^{5} /\right.$ well $) 100 \mu \mathrm{l}$ were added in this order. Cells and chemicals were diluted in complete media. Cells were then incubated at $37{ }^{\circ} \mathrm{C}$, $5 \% \mathrm{CO}_{2}$ for $48 \mathrm{~h}$ or $72 \mathrm{~h} .{ }^{3} \mathrm{H}$-thymidine $(0.5 \mu \mathrm{Ci} /$ well $)$ was added $6 \mathrm{~h}$ before the end of the experiment. At the end of the experiment cells were harvested and radioactivity was counted using a $\beta$ counter (Beckman). Results were expressed in cpm.

\subsubsection{Mouse Iymphocytes proliferation}

Splenocytes (mouse $\mathrm{C} 3 \mathrm{H}$ strain) were isolated from $\mathrm{C} 3 \mathrm{H}$ mice using mechanical dissection and counted using trypan blue.

Lymphocytes proliferation was induced using anti-CD3 antibody (1452C-11 hybridoma) directed to the epsilon chain of the murine CD3 complex. On the day of the experiment, cells $\left(4 \times 10^{5} /\right.$ well $) 50 \mu \mathrm{l}$, chemical $50 \mu \mathrm{l}$, complete media $50 \mu \mathrm{l}$ (RPMI 1640, penicillin, streptomycin, glutamine, sodium pyruvate, 2mercaptoethanol) at $5 \times 10^{-5} \mathrm{M},(10 \%$ fetal bovine serum $)$ and antibody $50 \mu \mathrm{l}$ $(10 \mu \mathrm{g} / \mathrm{ml})$ were added in this order. Cells, chemicals and antibody were diluted in complete media. Cells were then incubated at $37^{\circ} \mathrm{C}, 5 \% \mathrm{CO}_{2}$ for $48 \mathrm{~h}$ or $72 \mathrm{~h}$. ${ }^{3} \mathrm{H}$-thymidine $(0.5 \mu \mathrm{Ci} /$ well $)$ was added $6 \mathrm{~h}$ before the end of the experiment. At the end of the experiment cells were harvested and radioactivity was counted using a $\beta$ counter (Beckman). Results were expressed in cpm. 


\subsection{Proliferation test on rats cells}

\subsubsection{Animals}

SPF-bred female Wistar rats of the strain Hsd cpB:WU were used (Harlan Winkelmann $\mathrm{GmbH}$, Borchen, Germany).

\subsubsection{Cell material}

Cell suspensions obtained from spleen were tested. In a first step the optimal cell density for stimulation regimes with the $\mathrm{T}$ cell mitogen Concanavalin $\mathrm{A}$ was determined $1 \times 10^{5}$ cells/well $\left(2 \times 10^{6}\right.$ cells $\left./ \mathrm{ml}\right)$ were subsequently used.

Measurements were done in quadruplicates in each case $(50 \mu \mathrm{l} /$ well).

\subsubsection{Medium}

Cells were cultured in RPMI 1640 additioned with L-glutamin (Invitrogen Life Technologies, Karlsrhue, Germany), sodium pyruvate, MEM (non-essential amino acids), penicillin/streptomycin, $\beta$ mercaptoethanol and $5 \%$ mitogen free fetal calf serum.

\subsubsection{Mitogen stimulation}

Concanavalin A (ConA, Sigma) was used to stimulate cell proliferation. Cells were incubated for $24 \mathrm{~h}$ with ConA at the final concentrations of $2 \mu \mathrm{g} / \mathrm{ml}$.

The application volume was $50 \mu \mathrm{l} /$ well to give a final volume of $100 \mu \mathrm{l} /$ well $(50 \mu \mathrm{l}$ cell suspension and $50 \mu \mathrm{l}$ mitogen or medium alone).

\subsubsection{BrdU incorporation}

Mitogen stimulation was assessed by BrdU (5-bromo-2'deoxyuridine) incorporation using the Cell Proliferation ELISA BrdU Kit (Roche), following Supplier's specifications. The ELISA was purchased from Roche (Roche Diagnostics-Applied Science, Mannheim, Germany).

Briefly, $10 \mu \mathrm{l}$ of the BrdU solution in RPMI medium (1:100 diluent) was added to each well after incubation periods of $24 \mathrm{~h}$ or $48 \mathrm{~h}$. The plates were then incubated for another $24 \mathrm{~h}$ at $37{ }^{\circ} \mathrm{C}$ and $5 \% \mathrm{CO}_{2}$. After this final incubation period with $\mathrm{BrdU}$ the plates were centrifuged at $1200 \mathrm{rpm}$ for $10 \mathrm{~min}$, labeling medium carefully removed and plates dried at $60^{\circ} \mathrm{C}$ for $1 \mathrm{~h}$.

Cells were then incubated with FixDenat Reagent $200 \mu \mathrm{l} /$ well for $30 \mathrm{~min}$ at RT, then washed three times with buffer $300 \mu \mathrm{l} /$ well. Anti BrdU labeling was done adding $100 \mu \mathrm{l} /$ well for $60 \mathrm{~min}$ at RT and then washed with buffer $200 \mu \mathrm{l} /$ well, three times. Substrate solution $100 \mu \mathrm{l} /$ well was added and after about $8 \mathrm{~min}$ of incubation, $1 \mathrm{M} \mathrm{H}_{2} \mathrm{SO}_{4} 25 \mu \mathrm{l} /$ well was added to stop the reaction. Plates were mixed on a shaker for $1 \mathrm{~min}$ (300 rpm) and the absorbance read at $450 \mathrm{~nm} / 630 \mathrm{~nm}$. 


\subsubsection{MTT assay}

The analysis of cell viability was performed by the MTT assay. MTT solution $5 \mathrm{mg}$ $\mathrm{MTT} / \mathrm{ml}$ was prepared in sterile PBS (MTT, Sigma), while isopropanole/HCl solution (isopropanole Merck) was prepared mixing $100 \mathrm{ml}$ isopropanole with $0.4 \mathrm{ml} \mathrm{HCl} 10 \mathrm{~N}$.

Cell suspension was distributed on a 96 well plate, $100 \mu \mathrm{l}$ cell/well. Cells were incubated with mitogen for $24 \mathrm{~h}$ or $48 \mathrm{~h}$ at $37^{\circ} \mathrm{C}$ and $5 \% \mathrm{CO}_{2}$. After incubation, $10 \mu \mathrm{l} \mathrm{MTT}$ was added to $100 \mu \mathrm{l}$ cell suspension and cells were shaked (very slowly) for $4 \mathrm{~h}$ at $37^{\circ} \mathrm{C}$, then centrifuged at $1200 \mathrm{rpm}$ for $2 \mathrm{~min}$. Supernatant was carefully removed and $10 \mu \mathrm{l}$ of $3 \%$ SDS, $50 \mu \mathrm{l}$ isopropanole- $\mathrm{HCl}$ were added to each well and slowly shaked for $15 \mathrm{~min}$. Absorbance was evaluated by a photometer at $570 \mathrm{~nm}$, using $630 \mathrm{~nm}$ reference

\subsection{Proliferation test on mouse and rats cells}

Spleen cells from rat (Wistar Rivm:TOX, males) and mice (Balb/c, Rivm, males) were incubated for $24 \mathrm{~h}$ with increasing concentrations of the selected chemicals in six well-plates at $37^{\circ} \mathrm{C}$ and $5 \% \mathrm{CO}_{2}: 2.5 \mathrm{ml}$ of the chemical solution was added to $2.5 \mathrm{ml}$ of a cell suspension at $1 \times 10^{7}$ cells $/ \mathrm{ml}$ (RPMI 1640,1\% penicillin and streptomycin, 10\% FCS). After incubation, cells were harvested washed twice and resuspended at $4 \times 10^{6}$ cells $/ \mathrm{ml}$. Cell viability was assessed by trypan blue dye exclusion. To evaluate mitogen responsiveness, Concanavalin A (ICNbiochemicals), LPS from E. coli serotype O127:B8, (Sigma-Aldrich) and Lectin from Phytolacca Americana (Sigma-Aldrich) were used. In wells of 96 round bottom well plates $0.1 \mathrm{ml}$ of the cell suspension was added together with $0.05 \mathrm{ml}$ of the mitogens (final concentrations in the wells: ConA: $3.33 \mu \mathrm{g} / \mathrm{ml}$; LPS: $16.5 \mu \mathrm{g} / \mathrm{ml}$; Lectin: $5 \mu \mathrm{g} / \mathrm{ml}$ ) and incubated for $48 \mathrm{~h}$. Twenty hours before terminating the incubation, $3 \mathrm{H}$-thymidine (Amersham, $10 \mu \mathrm{l} / \mathrm{well}, 1 \mu \mathrm{Ci}$ ) was added. The cells were harvested on glass fibres filters (LKB-Wallac, Turku, Finland), using a multiple cell culture harvester (LKB-Wallac). Scintillation liquid (LKB-Wallac) was added to the filters and the radioactivity in the filters was counted in a liquid scintillation counter (LKB-Wallac).

Each test was performed in triplicate; spleen cells from rat were tested on an individual animal basis; spleen cells from mice were pooled and divided in three portions.

\subsection{LDH}

Three solutions were prepared: $50 \mathrm{mM}$ phosphate buffer, $60 \mathrm{mM}$ sodium pyruvate, $18 \mathrm{mM}$ NADH. These were used to prepare a reaction mixture: $50 \mathrm{mM}$ phosphate buffer $98 \mathrm{ml}, 60 \mathrm{mM}$ sodium pyruvate $1 \mathrm{ml}, 18 \mathrm{mM} \mathrm{NADH} 1 \mathrm{ml}$.

Cells were plated in 96 well plates (15,000/cells per well) and incubated in DMEM with $2 \mathrm{mM}$ glutamine, $10 \%$ FBS for $24 \mathrm{~h}$ and then treated with compounds.

After $24 \mathrm{~h}$ of incubation $1 \mathrm{ml}$ medium was collected from cell plates and kept on ice. The rest of medium was aspirated. Cells were washed twice with PBS without $\mathrm{Ca}^{2+}$ and $\mathrm{Mg}^{2+}$ and then scraped off after adding $1 \mathrm{ml}$ cold PBS without $\mathrm{Ca}^{2+}$ and $\mathrm{Mg}^{2+}$, to each well. Samples were collected in $1 \mathrm{ml}$ eppendorf tubes and kept on ice until processing. It is better to analyze samples straight after collecting them, however if this is not possible they can be kept at $4^{\circ} \mathrm{C}$ for $24 \mathrm{~h}$. Cells have to be sonicated just before analysis. About $1 \mathrm{ml}$ cuvettes were prepared with $20 \mu \mathrm{l}$ of 
sample and $1 \mathrm{ml}$ of reaction mixture. Samples were read one by one at $340 \mathrm{~nm}$ (2 min for each one).

Enzyme activity can be expressed as $\mu \mathrm{mol} / \mathrm{min}$ or $\mu \mathrm{mol} / \mathrm{min} / \mathrm{l}(\mathrm{U} / \mathrm{I})$ :

$$
\begin{aligned}
& \frac{\Delta A \text { bsorb. } \times V_{\mathrm{t}} \times 1000}{\varepsilon \times d \times \Delta t}=\frac{\mu \mathrm{mol}}{\min }
\end{aligned}
$$

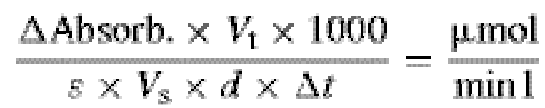

$V_{\mathrm{t}}$ is the total volume in the cuvette $(1020 \mu \mathrm{l}) . V_{\mathrm{s}}$ is the sample volume. the wave length. $d$ is the distance between the light origin and the cuvette. $\Delta t$ is the time of reading.

\subsection{Statistical analysis}

The concentrations which inhibit the $50 \%$ of growth (IC50) were calculated according to the Reed and Muench formula (Reed and Muench, 1938) and Hill function analysis. Data were expressed as mean \pm standard error of the mean.

\section{Results}

\subsection{Viability tests}

Before performing functional assays, cytotoxicity was evaluated through different tests: MTT, trypan blue dye exclusion and LDH. The IC50 values $(\mu \mathrm{M})$ obtained for each compound, after $24 \mathrm{~h}$ exposure, are reported in Table 1 . Not cytotoxic concentrations were used for proliferation and cytokine release analysis.

Table 1.

Viability data

\begin{tabular}{|l|l|l|l|}
\hline Compounds & \multicolumn{3}{|l|}{ Cytotoxicity tests: IC50 $(\boldsymbol{\mu M})$} \\
\hline & Mouse & Rat & Human \\
\hline Urethane & $>10,000$ & $>10,000$ & $>10,000$ \\
\hline Furosemide & $>1000$ & $>1000$ & $>1000$ \\
\hline Verapamil & $>15$ & $>15$ & $>100$ \\
\hline Benzo $(a)$ pyrene & $>200$ & $>200$ & $>50$ \\
\hline Cyclosporin A & $15.61( \pm 1.9)$ & $>6$ & $>5$ \\
\hline TBTC & $0.046( \pm 0.06)$ & $0.02( \pm 0.001)$ & $>0.1$ \\
\hline
\end{tabular}

This table summarizes cytotoxic test results performed by all laboratories participating on this study. 


\subsection{CFU-GM test}

In Fig. 1 dose-response curves of the selected compounds tested are reported. Urethane treatment decreased the colony number only at very high concentrations $(1000 \mu \mathrm{M})$, while for Furosemide there was no decrease in the colony number at the concentrations tested. Verapamil, Benzopyrene, Cyclosporin $A$ and TBTC induced a dose-related decrease in the colony number after 14 days exposure.
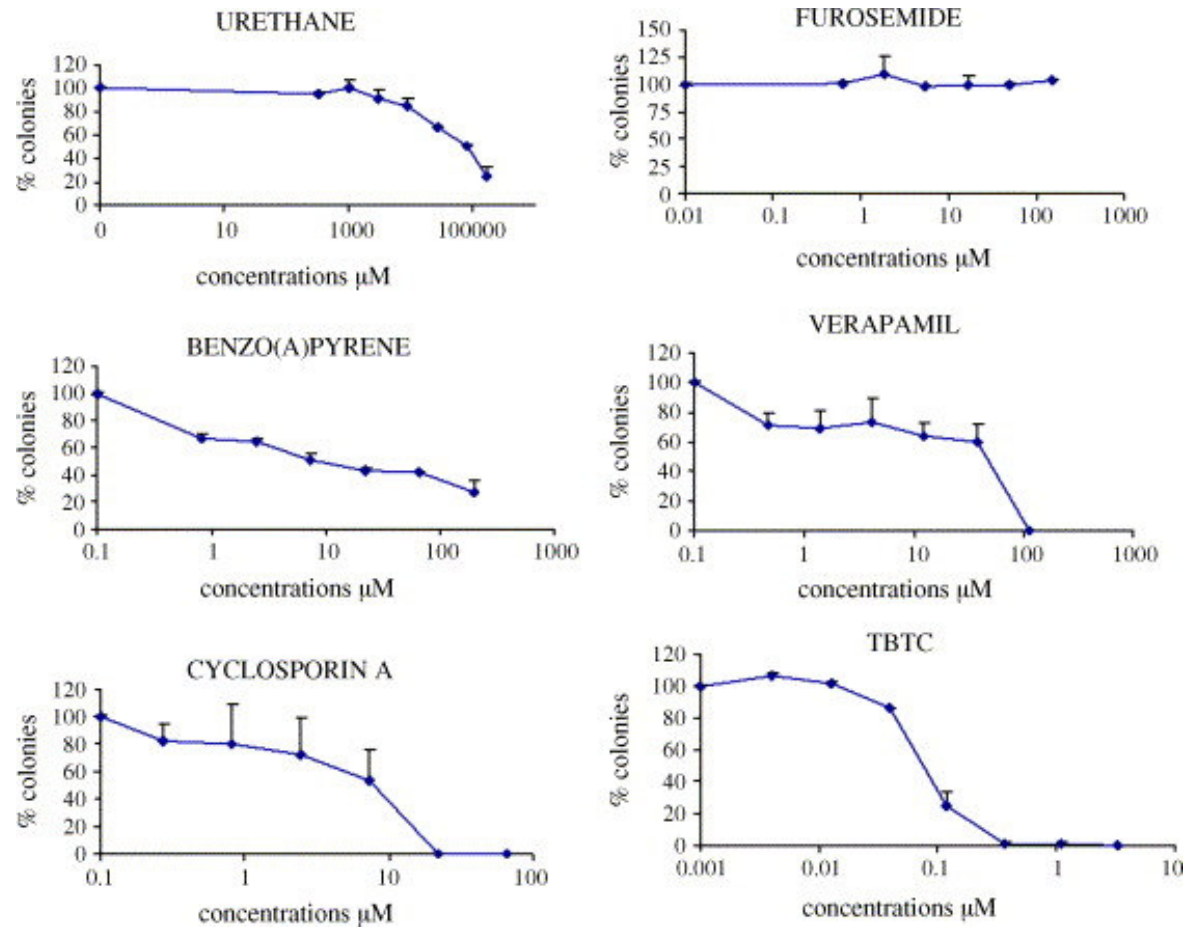

Fig. 1. CFU-GM test-graphs show the colonies number counted at different compound concentrations $(\mu \mathrm{M})$. Colonies were counted after 14 days exposure.

\subsection{Mitogen stimulation on rodent spleen cells}

Rat and mouse spleen cells were treated with chemicals for $24 \mathrm{~h}$ and then with LPS or PHA for $48 \mathrm{~h}$ to assess mitogen responsiveness. In Fig. 2, the IC50 values calculated for each compound in both species are reported. All positive compounds inhibited cell proliferation. The IC50 values were in the same range for both rat and mouse for all substances tested, a part from TBTC for which rat IC50 was higher than mouse IC50 $(0.007 \pm 0.0002$ versus $0.002 \pm 0.0002$ with $\mathrm{PHA}, 0.007 \pm 0.0006$ versus $0.0025 \pm 0.0002$ with LPS). The negative compounds failed to modulate mitogen response (data not shown). 

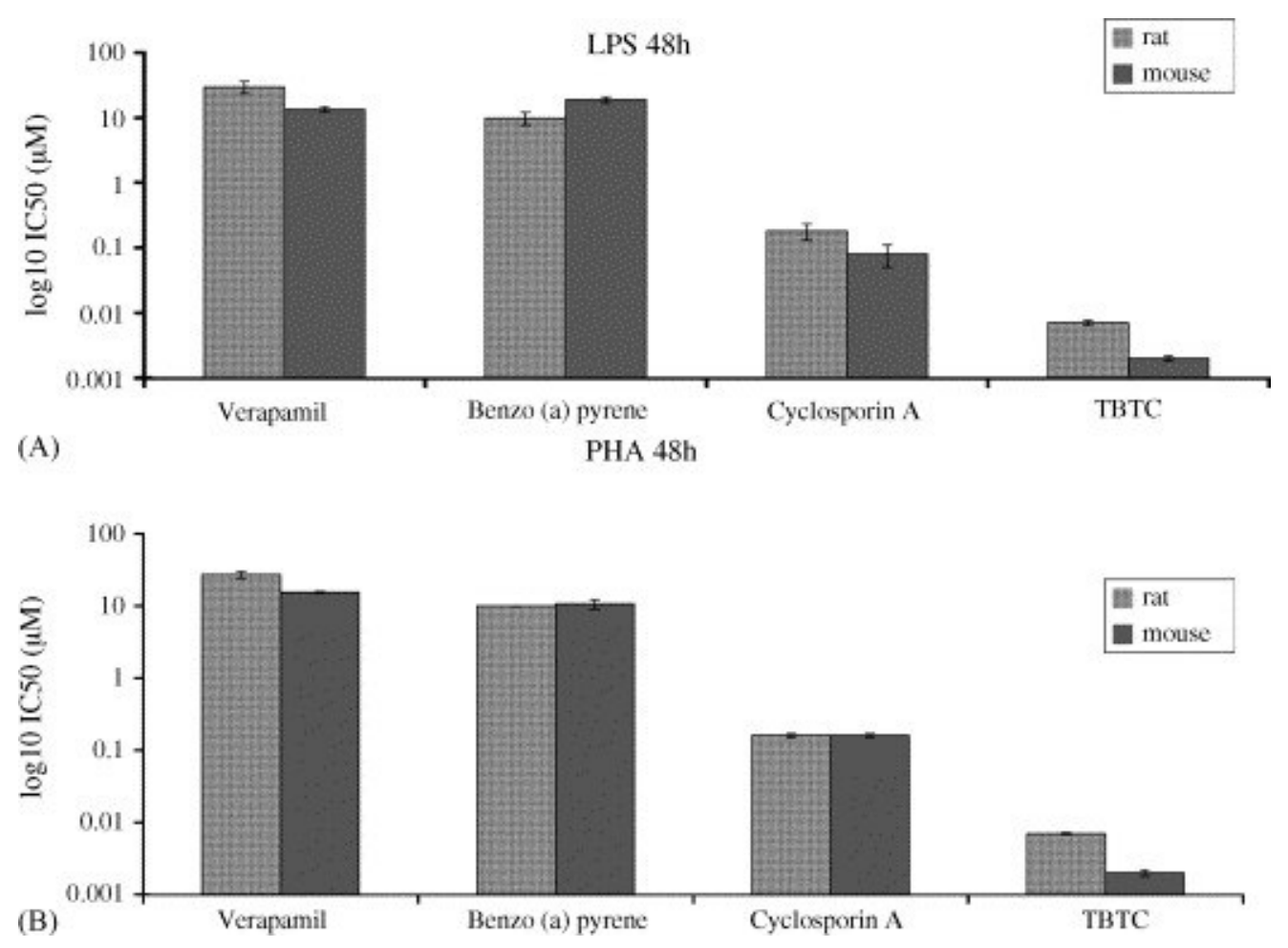

Fig. 2. Comparison between rat and mouse IC50 values. (A) LPS stimulation at $48 \mathrm{~h}$. (B) PHA stimulation at $48 \mathrm{~h}$. $3 \mathrm{H}$-thymidine was added to assess mitogen responsiveness.

Rat spleen cells were also stimulated with ConA at $48 \mathrm{~h}$ or $24 \mathrm{~h}$ (Fig. 3). IC50 values were higher after $24 \mathrm{~h}$ stimulation than after $48 \mathrm{~h}$ for all compounds tested.

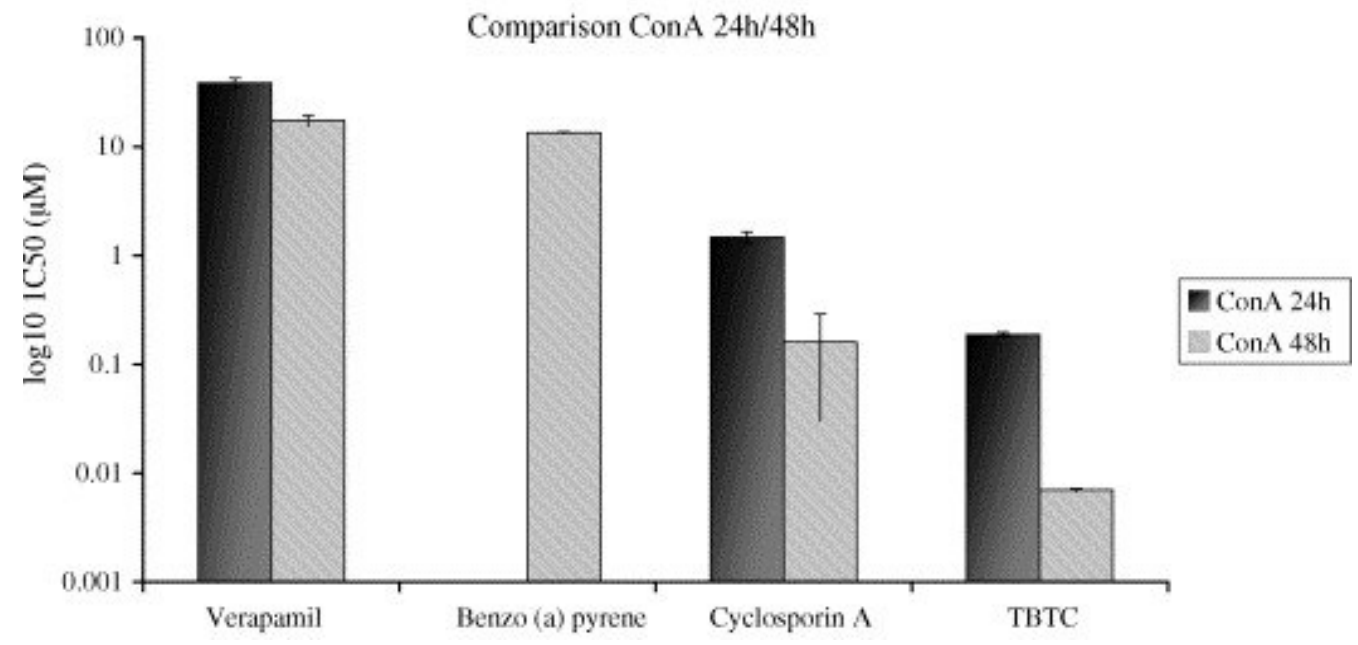

Fig. 3. Comparison between ConA treatment at $24 \mathrm{~h}$ and $48 \mathrm{~h}$. Rat spleen cells were treated with compounds and then stimulated with ConA for $24 \mathrm{~h}$. In the second case cells were treated with compound and mitogen for $48 \mathrm{~h}$. 


\subsection{Anti-CD3 antibody stimulation on mouse spleen cells and human lymphocytes}

Mouse and human cells were treated with anti-CD3 antibody to stimulate $T$ lymphocyte proliferation. In Table 2 the IC50 values calculated after treatment are reported. Also in this case, both Urethane and Furosemide were confirmed negative in both the two species.

Table 2.

Anti-CD3 antibody stimulation

\begin{tabular}{|l|l|l|}
\hline Compounds & \multicolumn{2}{|l|}{ Anti-CD3 antibody stimulation: IC50 $(\boldsymbol{\mu M})$} \\
\hline & Mouse lymphocytes & Human lymphocytes \\
\hline Urethane & $>10,000$ & $>17,000$ \\
\hline Furosemide & $>1000$ & $>100$ \\
\hline Verapamil & $30.27( \pm 3.5)$ & $20.95( \pm 1.16)$ \\
\hline Benzo $(a)$ pyrene & $>160$ & $12.82( \pm 1.11)$ \\
\hline Cyclosporin A & $0.13( \pm 0.05)$ & $1.00( \pm 0.13)$ \\
\hline TBTC & $>0.1$ & Not tested \\
\hline
\end{tabular}

Cells from mouse lymphocytes and from human peripheral blood have been stimulated with anti-CD3 antibody and treated with compounds. IC50 values $(\mu \mathrm{M})$ have been calculated.

The effect of Benzo(a)pyrene among mouse and human cells was very different: the IC50 values was $12.82( \pm 1.11) \mu \mathrm{M}$ for human lymphocytes, while the compound did not inhibit murine cells proliferation even at the highest dose tested.

The IC50 value for Cyclosporin A was 10 time higher in human than in mouse lymphocytes, while the IC50 values for Verapamil were similar between mouse and human lymphocytes.

\subsection{Cytokine release from human lymphocytes}

The effect of the selected chemicals on cytokine production was assessed using the whole blood assay. Each chemical was tested in at least three donors. Since the amount of cytokines produced varies among donors, it was not possible to combine values, and therefore it was more meaningful to compare the trend of modulation. In fact, despite the different cytokine produced the effects of the different chemicals were consistent among donors.

In Fig. 4 are reported the effect of the selected chemicals on a representative donor, while in Table 3 the data are summarized. The " + " symbol means that cytokine release is modulated (both as increase or decrease), while the "-" symbol means that there is no modulation in respect to vehicle treated cells. Compounds tested were classified as positive if one or more parameters were 
altered at, at least, one concentration or only one parameter in a dose-related fashion in more than one donor.
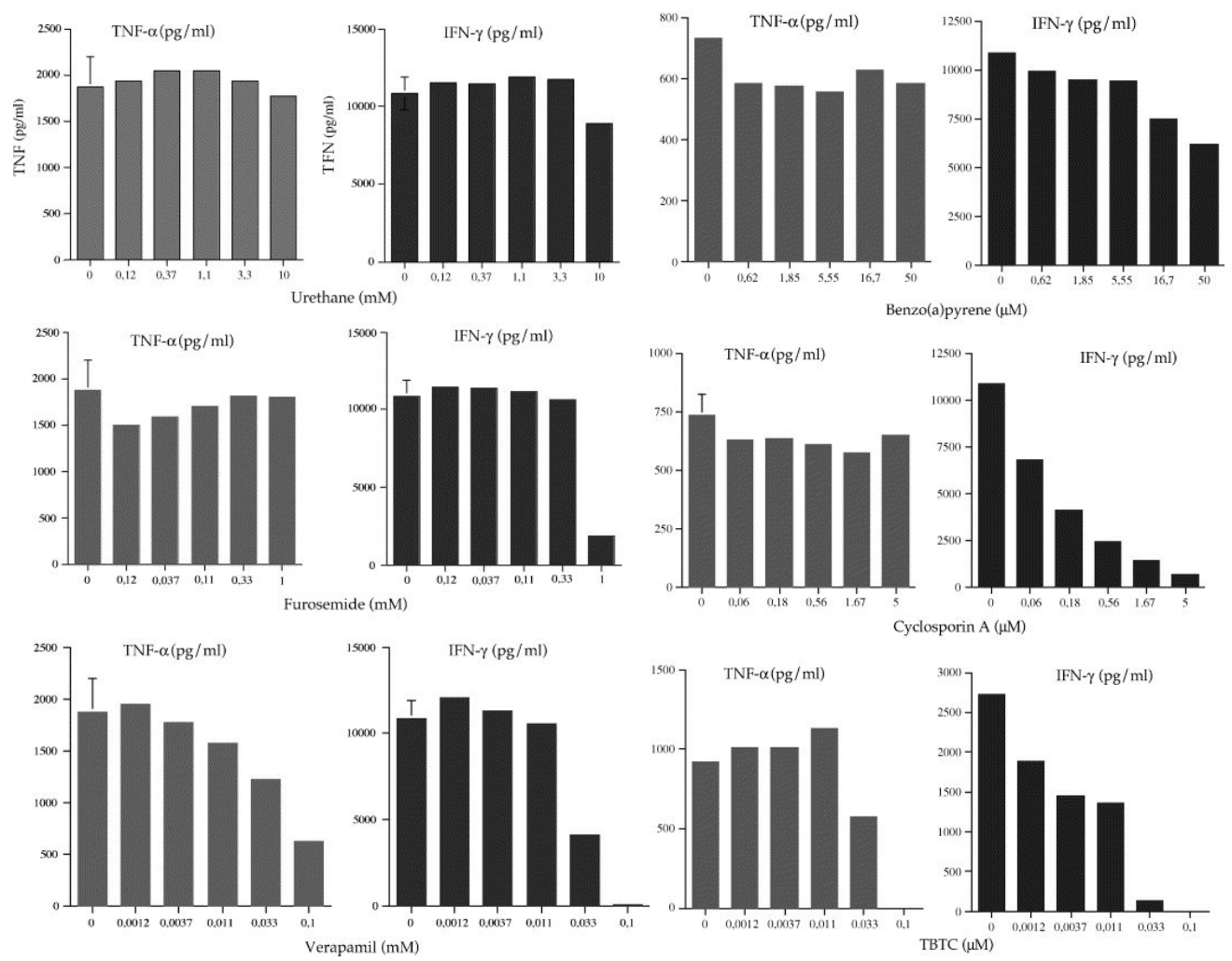

Fig. 4. Cytokine modulation on a representative donor. Graphs on the left show the TNF-a $(\mathrm{pg} / \mathrm{ml})$ release upon LPS and compound stimulation. Graphs on the right show INF-Y $(\mathrm{pg} / \mathrm{ml})$ release upon PHA and compound stimulation.

Table 3.

Cytokine release analysis

\begin{tabular}{|c|c|c|c|c|c|c|c|c|c|}
\hline \multirow[t]{2}{*}{ Compounds } & \multicolumn{2}{|c|}{$\begin{array}{l}\text { Donor } \\
\text { \#1 }\end{array}$} & \multicolumn{2}{|c|}{$\begin{array}{l}\text { Donor } \\
\text { \#2 }\end{array}$} & \multicolumn{2}{|c|}{$\begin{array}{l}\text { Donor } \\
\text { \#3 }\end{array}$} & \multicolumn{2}{|c|}{$\begin{array}{l}\text { Donor } \\
\text { \#4 }\end{array}$} & \multirow[t]{2}{*}{ Classification } \\
\hline & TNF & IFN & TNF & IFN & TNF & IFN & TNF & IFN & \\
\hline Urethane & - & - & - & + & - & & - & - & $\mathrm{N}$ \\
\hline Furosemide & - & + & - & + & - & & - & + & Cytotoxicity \\
\hline Verapamil & + & + & + & + & + & & + & + & $P$ \\
\hline Benzo(a)pyrene & + & + & - & + & + & & - & + & $P$ \\
\hline Cyclosporin A & - & + & - & + & - & & - & + & $P$ \\
\hline ТВTC & + & + & + & + & + & & & & $P$ \\
\hline
\end{tabular}


INF- $y$ was measured after $72 \mathrm{~h}$ PHA stimulation, TNF-a after 72 h LPS stimulation. ' + ' symbol means that there is a variation in cytokine releasing which can be an increase or a decrease; '-' symbol means invariability. P stays for positive (immunotoxic), while $\mathrm{N}$ negative. Furosemide cannot be classified.

All four positive compounds modulated PHA-induced IFN release, and with the exception of Cyclosporin A, they also modulated LPS-induced TNF-a release. The negative compound Urethane was overall unable to affect TNF-a and IFN-Y production, while Furosemide at high concentrations, which resulted to be cytotoxic, decreased PHA-induced IFN-y release, while TNF-a release was not affected.

\subsection{IC50 comparison through different species}

Where applicable, for each compound tested the IC50 was calculated and results compared by species. Table 4 shows that Urethane and Furosemide were confirmed as not immunotoxic. Verapamil and Benzo(a)pyrene IC50 values were in the same range for both rodents and human. Cyclosporin A and TBTC IC50 is higher in human than in rodents. Mouse seemed, in particular, the most sensitive to Cyclosporin A and TBTC treatment.

Table 4.

IC50 comparison

\begin{tabular}{|l|l|l|l|}
\hline Compounds & Mouse & Rat & Human \\
\hline Urethane & No effect & No effect & No effect \\
\hline Furosemide & No effect & No effect & No effect \\
\hline Verapamil & $13<$ IC50 $<30$ & $17<$ IC50 $<30$ & $20<$ IC50 $<22$ \\
\hline Benzo(a)pyrene & $10<$ IC50 $<18$ & $9<$ IC50 $<13$ & $11<$ IC50 $<12$ \\
\hline Cyclosporin A & $0.08<$ IC50 $<0.3$ & $0.16<$ IC50 $<0.18$ & $1<$ IC50 $<8$ \\
\hline TBTC & $0.002<$ IC50 $<0.003$ & 0.007 & 0.07 \\
\hline
\end{tabular}

The IC50 values $(\mu \mathrm{M})$ obtained from each different test are reported as range. "No effect" means that the compound is not immunotoxic.

All tests performed showed that from Verapamil to TBTC toxicity increase, with the same trend in all species.

\section{Discussion}

At present, no validated in vitro tests are available that can replace (Hartung et al., 2004) in vivo methods to evaluate immunotoxicity (Gennari et al., 2005). Significant progresses have been made in the last years to promote the establishment of new sensitive methods to assess immunotoxicity (Wagner et al., 2006 and Dean, 1997).

The purpose of this study was to assess and compare the potentiality of different in vitro tests to correctly identify known immunotoxic compounds. Overall, all 
assays were able to correctly classify the selected chemicals. At present, in vivo immunotoxicity assessment relays on weights of lymphoid organs, histopathology of primary and secondary lymphoid organs, total white blood cell counts, immunophenotyping of peripheral blood leukocytes and quantification of total serum immunoglobulin levels. In vitro models could be used for pre-screening of immunotoxic potential, as a strategy. One could start from evaluation of myelotoxicity; compounds that damage or destroy the bone marrow are immunotoxic, since all progenitors derive from the pluripotent stem cells present in the bone marrow (Luster et al., 1985 and Kim et al., 2001). Thus, if a compound is myelotoxic it would not be necessary to evaluate other endpoints. The methodology for evaluating myelotoxicity, in vitro, the CFU-GM test, has been recently validated (Pessina et al., 2003). In addition, compounds that are not myelotoxic may affect lymphocytes which are the primary effectors and regulators of acquired immunity. If the cells are viable ( $80 \%$ or greater) basic functionality can be determined assessing cell proliferation using mitogens such as plant lectin (PHA, ConA) or anti-CD3 and anti-CD28 antibody (especially for $T$ cells). In parallel, proper immune functionality depends on cytokine production and their quantitative alterations can also be considered as a measure of immunomodulation (Gennari et al., 2005).

There is also the need to use more than one end-point due to the complexity of the immune system and to the different mechanism of action of the compounds (Lebrec et al., 1995).

In the present study, both cell proliferation and cytokine production were used to assess the immunotoxic potential of xenobiotics. Both proliferation and cytokine release are considered to be very relevant to investigate the toxicity towards the immune system (Langezaal et al., 2001). Proliferation was evaluated with CFUGM test, with Anti-CD3 antibody stimulation and with different mitogens (LPS and some lectins). Despite differences between tests used and the different species analyzed, all tests agreed in classifying compounds through all species. Urethane and Furosemide were confirmed not immunotoxic. Other compounds revealed immunotoxic with an increasing toxicity degree from Verapamil to TBTC, in all species. Verapamil and Benzo(a)pyrene immunotoxicity, generally, was similar in all species, while Cyclosporin A and TBTC seemed to have a stronger toxic effect on mouse than on rat cells. Human cells were more resistant than rodents cells to Cyclosporin A and TBTC treatment, in fact IC50 values were 10 times higher in human than in rat cells. The comparison between IC50 values from CFU-GM test and anti-CD3 stimulation on human cells showed a different sensitivity to Cyclosporin A. The CFU-GM assay measured the clonogenicity of myeloid progenitors, whereas anti-CD3 antibody stimulates specifically $T$ lymphocytes which are the primary target of Cyclosporin A toxicity (Sigal et al., 1991). This put in evidence the mechanism of action of the drug and the ability of the two tests to discriminate the proliferation of different cell populations.

Regarding cytokines release, IFN- $\mathrm{Y}$ and TNF- $\mathrm{a}$ were used as markers. TNF- $\mathrm{a}$ is a pleiotropic inflammatory cytokine, produced by several types of cells, but especially by macrophage. TNF-a plays an important role in the immune response to bacterial, and certain fungal, viral, and parasitic invasions as well as in the necrosis of specific tumors (Janeway et al., 1999). IFN-Y is produced by lymphocytes activated by specific antigens or mitogens and is a potent activator of macrophages.

The amount of cytokine produced depends not only on the treatment but also on the donor. It is, however, possible to observe the same trend among the different donors. At least three donors should be used to establish consistency and more 
Toxicology Volume 229, Issues 1-2, 5 January 2007, Pages 11-22

than one end point should be considered: INF- $\gamma$ resulted more modulated than TNF-a, probably because the compounds tested had mainly lymphocytes as target cells.

Cytokine release analysis agreed with proliferation tests results, in compounds classification, as discussed before.

\section{Conclusion}

This preliminary study shows that, in vitro tests performed well in classifying the selected compounds (both chemicals and drugs). Each test analyzes a particular aspect of immunotoxicity, for this reason is important to develop an integrated system able to detect the most relevant endpoints. In the next phase, immunostimulation will be also considered.

A comparison between different tests performance will be established and a formal pre-validation study will be set-up on the most promising methods.

\section{References}

Balls et al., 1995 M. Balls, A.M. Goldberg, J.H. Fentem, C.L. Broadhead, R.L. Burch, M.F.W. Festing, J.M. Frazier, C.F.M. Hendriksen, M. Jennings, M.D.O. Van der Kamp, D.B. Morton, A.N. Rowan, C. Russell, W.M.S. Russell, H. Spielmann, M.L. Stephens, W.S. Stokes, D.W. Straughan, J.D. Yager, J. Zurlo and B.F.M. Van Zutphen, The three Rs: the way forward. ECVAM Workshop Report 11, ATLA 23 (1995), pp. 838-866.

Birx et al., 1984 D.L. Birx, M. Berger and T.A. Fleisher, The interference of T cell activation by calcium channel blocking age, J. Immunol. 133 (1984) (6), pp. 2904-2909.

Chow and Jusko, 2004 F.-S. Chow and J.W. Jusko, Immunosuppressive interactions among calcium channel antagonists and selected corticosteroids and macrolides using human whole blood lymphocytes, Drug Metabol. Pharmacokinet. 19 (2004) (6), pp. 413-421.

COM, 2003 COM, 2003. 644: http://europa.eu.int/eur-lex/en/com/pdf/2003/com2003_0644en.html.

Dean, 1997 J.H. Dean, Issues with introducing new immunotoxicology methods into the safety assessment of pharmaceuticals, Toxicology 119 (1997) (1), pp. 95-101.

Gennari et al., 2005 A. Gennari, M. Ban, A. Braun, S. Casati, E. Corsini, J. Dastych, J. Descotes, T. Hartung, R. Hooghe-Peters, R. House, M. Pallardy, R. Pieters, L. Reid, H. Tryphonas, E. Tschirhart, H. Tuschl, R. Vandebriel and L. Gribaldo, The use of in vitro system for evaluating immunotoxicity: the report and recommendations of an ECVAM workshop, J. Immunotoxicol. 2 (2005), pp. 61-83.

Genshow et al., 2002 E. Genshow, H. Spielmann, G. Scholz, A. Seiler, N. Brown, A. Piersma, M. Brady, N. Clemann, H. Huuskonen, F. Paillard, S. Bremer and K. Becker, The ECVAM international validation study on in vitro embryotoxicity tests: results of the definitive phase and evaluation of prediction models, Alternatives Lab. Anim. 30 (2002), pp. 151-176.

Hartung et al., 2004 T. Hartung, S. Bremer, S. Casati, S. Coecke, R. Corvi, S. Fortaner, L. Gribaldo, M. Halder, S. Hoffmann, A. Janusch Roi, P. Prieto, E. Sabbioni, L. Scott, A. Worth and V. Zuang, A modular approach to the ECVAM principles on test validity, ATLA 32 (2004), pp. 467-472.

HSDB, 2000 HSDB: Hazardous Substances Data Base, 2000. National Library of Medicine. http://toxnet.nlm.nih.gov/cgi-bin/sis/htmlgen?HSDB.

IARC, 1983 IARC, 1983. 32, 225.

Janeway et al., 1999 C. Janeway, P. Travers, M. Walport and J. Capra, Immunobiology: the Immune System in Health and Disease, Garland Publishers, New York, NY (1999). 
Kim et al., 2001 S. Kim, J.W. Lish, L. Stai Eric, R.L. Lochmiller, D.P. Rafferty and C.W. Qualls, Evaluation of myelotoxicity in cotton rats (Sigmodon hispidus) exposed to environmental contaminants. II. Myelotoxicity associated with petroleum industrial wastes, J. Toxicol. Environ. Health Part A 62 (2001) (2), pp. 97-105.

Kimura et al., 2005 K. Kimura, K. Kobayashi, H. Naito, Y. Suzuki and Y. Sugita-Konishi, Effect of lactational exposure to tributyltin chloride on innate immunodefenses in the F1 generation in mice, Biosci. Biotechnol. Biochem. 69 (2005) (6), pp. 1104-1110.

Kirchner et al., $1982 \mathrm{H}$. Kirchner, C. Kleinicke and W. Digel, A whole blood technique for testing production of human interferon by leukocytes, J. Immunol. Meth. 48 (1982), pp. 213-219.

Langezaal et al., $2001 \mathrm{I}$. Langezaal, S. Coecke and T. Hartung, Whole blood cytokine response as a measure of immunotoxicity, Toxicol. In Vitro 15 (2001) (4-5), pp. 313-318.

Lebrec et al., 1995 H. Lebrec, R. Roger, C. Blot, G.R. Burleson, C. Bohuon and M. Pallardy, Immunotoxicological investigation using pharmaceutical drugs. In vitro evaluation of immune effects using rodent or human immune cells, Toxicology 96 (1995) (2), pp. 147-156

Luster et al., 1985 M.I. Luster, H.L. Hong, G.A. Boorman, G. Clark, H.T. Hayes, W.F. Greenlee, K. Dold and A.N. Tucker, Acute myelotoxic responses in mice exposed to 2,3,7,8-tetrachlorodibenzo $p$-dioxin (TCDD), Toxicol. Appl. Pharmacol. 81 (1985), pp. 156-165.

Martindale, 2002a Martindale, 2002a. "The complete drug reference", 'Eds 33'. Pharmaceutical Press, London, pp. 893-896.

Martindale, 2002b Martindale, 2002b. "The complete drug reference", 'Eds 33'. Pharmaceutical Press, London, pp. 518-524.

Pessina et al., 2001 A. Pessina, B. Albella, J. Bueren, P. Brantom, S. Casati, L. Gribaldo, C. Croera, G. Gagliardi, P. Foti, R. Parchment, D. Parent-Massin, Y. Sibiril, G. Schoeters and R. Van Den Heuvel, Prevalidation of a model for predicting acute neutropenia by colony forming unit granulocyte/macrophage (CFU-GM) assay, Toxicol. In Vitro 15 (2001), pp. 729-740.

Pessina et al., 2003 A. Pessina, B. Albella, M. Bayo, J. Bueren, P. Brantom, S. Casati, C. Croera, G. Gagliardi, P. Foti, R. Parchment, D. Parent-Massin, G. Schoeters, Y. Sibiril, R. Van Den Heuvel and L. Gribaldo, Application of the CFU-GM assay to predict acute drug-induced neutropenia: an international blind trial to validate a prediction model for the maximum tolerated dose (MTD) of myelosuppressive xenobiotics, Toxicol. Sci. 75 (2003), pp. 355-367.

Reed and Muench, 1938 L.J. Reed and H.A. Muench, A simple method of estimating fifty percent endpoints, Am. J. Hyg. 27 (1938), pp. 493-497.

Sigal et al., 1991 N.H. Sigal, F. Dumont, P. Durette, J.J. Siekierka, L. Peterson, D.H. Rich, B.E. Dunlap, M.J. Staruch, M.R. Melino, S.L. Koprak, D. Williams, B. Witzel and J.M. Pisano, J. Exp. Med. 173 (1991), pp. 619-628.

Snodin, 2004 D.J. Snodin, Regulatory immunotoxicology: does the published evidence support mandatory nonclinical immune function screening in drug development?, Regul. Toxicol. Pharmacol. 40 (2004), pp. 336-355.

Snoeij et al., 1987 N.J. Snoeij, A.H. Penninks and W. Seinen, Biological activity of organotin compounds-an overview, Environ. Res. 44 (1987) (2), pp. 335-353.

Wagner et al., 2006 W. Wagner, A. Walczak-Drzewiecka, A. Ślusarczyk, P. Biecek, L. Rychlewski and J. Dastych, Fluorescent cell chip a new in vitro approach for immunotoxicity screening, Toxicol. Lett. 162 (2006), pp. 55-70. 